years his special researches dealt with alternating current machinery, particularly the synchronous induction motor and the rotary converter under transient conditions. He received the M.Sc. degree in 1920 and the D.Sc. degree in 1930, and when the chair of electrical engineering was instituted he was appointed to it. Latterly, his main interest has been in illumination engineering, which appears as an optional subject in the honours courses in electrical engineering. He published a treatise "Electric Discharge Lamps" in 1946 ; but in spite of a number of more important works his name is most intimately associated with his widely used "Electrical Technology".

\section{Dr. J. E. Parton}

Dr. John Edwin Parton, who is to succeed Prof. Cotton, is at present lecturer in the Department of Electrical Engineering, University of Glasgow. Dr. Parton entered the University of Birmingham after a period of industrial experience, and he graduated B.Sc. with first-class honours in 1936 and Ph.D. in 1938. He was then on the staff of the Post Office Engineering Department and Research Station. Dr. Parton served in the Royal Navy during 1939-45, and was demobilized with the rank of lieutenant, commander R.N.V.R. He was then appointed as a senior scientific officer in the British Iron and Steel Research Association before becoming a lecturer in the University of Glasgow in 1946. From 1949 to the present time, Dr. Parton has been responsible for teaching and research in the University on electrical machinery. $\mathrm{He}$ has published numerous papers on incremental magnetization in iron and on related problems, upon which he is a recognized authority; on the theory of machines and transformers ; and on general circuit theory. Dr. Parton is a full member of the Institution of Flectrical Engineers, of the Institution of Engineers and Shipbuilders in Scotland and of the American Institute of Radio Engineers ; and he is an associate member of the Institution of Mechanical Engineers.

Philosophy at Leeds :

Dr. S. E. Toulmin

Dr. S. E. Toulmin, at present lecturer in the philosophy of science in the Faculty of Literæ Humaniores of the University of Oxford, has been appointed to the chair of philosophy in the University of Leeds in succession to Prof. J. W. Harvey, who will retire at the end of the present academic year. Dr. Toulmin is a graduate in mathematics and natural sciences of King's College, Cambridge, taking his B.A. in 1943, and during 1942-45 he served as a junior scientific officer, Ministry of Aircraft Production, being first employed at the Great Malvern radar research and development station and later being attached to the Supreme Headquarters of the Allied Expeditionary Force for technical intelligence work in Germany. From 1947 until 1951 he was a Fellow of King's College, during which period he was awarded the Arnold Gerstenberg Studentship for research in philosophy, and gained his Ph.D. Dr. Toulmin has recently been appointed by the University of Melbourne, under the scheme for Commonwealth university interchange, to take charge of the Department of History and Methods of Science for the academic year 1954-55, and he will not go to Leeds until the beginning of the academic year 1955-56. He has published two books, "The Place of Reason in Ethics" and "The Philosophy of Science: an Introduction", and has also given several series of broadeast talks.

\section{Division of Animal Health and Production,} C.S.I.R.O., Australia

DR. L. B. BULL, chief of the Division of Animal Health and Production of the Commonwealth Scientific and Industrial Research Organization, Australia, will be retiring on June 30 , and will be succeeded by Mr. D. A. Gill, at present an assistant chief of the Division and officer-in-charge of the McMaster Animal Health Laboratory, Sydney. Mr. Gill was born in England and graduated as a member of the Royal College of Veterinary Surgeons. In 1925 he went to New Zealand as assistant director of the Veterinary Research Laboratory of the Department of Agriculture at Wallaceville (near Wellington), and then in 1933 he moved to Australia, working for two years at the McMaster Animal Health Laboratory and the University of Sydney as a veterinary pathologist and bacteriologist. After returning to New Zealand as district supervisor in the Department of Agriculture, he went back once more to the McMaster Laboratory in 1937 as officer-in-charge and has continued in that position, except for a period of a year or so during the Second World War when he acted as adviser to the Department of War Organization of Industry on rural matters. Mr. Gill's scientific work has dealt mainly with diseases and pests of sheep. He will be succeeded by Dr. D. F. Stewart as officer-in-charge of the McMaster Laboratory; at the same time, Dr. T. S. Gregory will become officer-in-charge of the Division's Animal Health Laboratory at Parkville (Melbourne).

\section{George Kelley Readership in Oxford in Metallurgy}

At a meeting of Congregation held on June 1, the University of Oxford accepted the offer of the Pressed Steel Co., Ltd., to establish a readership in metallurgy, in memory of the late Dr. George Kelley, who was formerly managing director of the Company. Dr. Kelley was an American who graduated at Harvard University, where he spent some years as a lecturer and associate professor. $\mathrm{He}$ joined the Pressed Steel Co. in 1931, and took a great interest in industrial and economic matters, and in the wellbeing of employees under his control. During his years at Oxford he became acquainted with many members of the University, and for his contributions to science and industry he received an honorary M.A. degree in 1943. He played a prominent part in creating the friendiy relations existing between the University and the industries of modern Oxford, and it is fitting that his name should be perpetuated in connexion with metallurgy, in which his chief interest lay. The research fellowships established by the Pressed Steel Co. have provided a great stimulus to University research, and the gift of a readership in metallurgy is a further example of the Company's generosity. Research work in metallurgy has been carried out in Oxford for twenty-eight years, and in 1949 metallography was accepted as an official Supplementary Subject. The George Kelley readership marks a further stage in the establishment of metallurgy in the University, and is a great encouragement to those concerned with metallurgical science.

\section{Trans-European Television}

A MAJOR step in the development of international television was taken on June 6 with the beginning of one month's interchange of television programmes between eight countries-Belgium, Denmark, France, 